\title{
El Raval and Mile End: A Comparative Study of Two Cultural Quarters between Urban Regeneration and Creative Clusters
}

\author{
Diane-Gabrielle Tremblay \& Angelo Battaglia \\ Community-University Research Alliance \\ 100 Sherbrooke Ouest (west), Montréal, Québec H2X 3P2, Canada \\ E-mail: tremblay.diane-gabrielle@teluq.ca
}

Received: December 28, 2011 Accepted: January 16, 2012 Published: March 1, 2012

doi:10.5539/jgg.v4n1p56 URL: http://dx.doi.org/10.5539/jgg.v4n1p56

\begin{abstract}
This research aims at clarifying the development of creative and cultural clusters embedded in two emerging artistic neighbourhoods in Barcelona and Montreal. This comparative study intends to consider these quarters as new cultural centralities located in ex-industrial areas and it demonstrates how the cultural regeneration as well as urban planning are two fundamental dimensions for re-structuring these post-modern cities. After the decline of the industrial sectors it will be necessary to regenerate and to reconvert these dismissed spaces and marginalized quarters in order to define a new urban identity which organizes the urban space in terms of systemic and inclusive approaches. We have studied these phenomena and we have tried to highlight how two similar cities are leading to establish a new functionality in terms of socio-economic, cultural and territorial development.
\end{abstract}

Keywords: Creative cluster, Cultural cluster, Clusters, Barcelona, Montreal, Territory, Local development

\section{Introduction}

The present article intends to clarify the dynamics of local development according to the processes of urban and cultural planning in artistic and cultural quarters, particularly those located in Barcelona and Montreal. It attempts to understand how the process of territorial and urban renewal, based on the culture-led regeneration approach, concretely transforms formally industrial spaces. In order to assess the strategic choices supported by urban planning and urban identity changes, it is necessary to measure the real effects of an integrated regeneration, in terms of social cohesion, innovation and empowerment. This study exposes a number of questions and applies them to case studies of Raval in Barcelona and Mile End in Montreal. First of all, we examine whether policies of territorial and socio-economic regeneration applied to cultural quarters produce a real renewal on a local scale, or if they represent discontinuous projects that forego punctual changes which are not integrated in terms of cultural and socio-economic revitalization.

Does the intensive regeneration process represent a multidimensional strategy that takes into account a range of socio-territorial actors at horizontal-complementary level? Or does it reflect a vertical and hierarchical model of urban planning and management?

By answering these questions, this comparative study on creative and cultural quarters in Barcelona and Montreal focuses on the main factors of a city's regeneration, according to the culture led-regeneration model. It also encourages the debate for policy makers and local administrations to establish a new policy for implementing an integrated strategic-cultural repositioning of the city, according to a multidimensional and multilayer approach.

The present text is structured in three different parts which analyze the dynamics of spatial and socio-economic re-organization for cultural and creative quarters in Barcelona and Montreal.

The first part analyzes the nature and the definition of cultural and creative quarters and assesses their role in enhancing creative and cultural city.

The second part produces case studies that examine the relationship between the cultural-creative spheres, systems of knowledge economy and local economies in Raval and Mile End. 
The third part compares the two case studies. Focusing on the main elements of territorial and cultural development, and the role of actors in their respective contexts, it suggests new urban practices for local renewal strategies.

Evans (2009) suggests a classification of cultural quarters and creative quarters, defining specific features depending on an economic, a social and a cultural framework. The first typology is founded on a process of local economic development with a high range of place-making branding, where the zoning and the regeneration in terms of "culture" are key elements of orientation. These "cultural quarters" have a high level of historic preservation and conservation; and are identified as festival and cultural centers in a cultural city. Secondly, the creative quarters are mixed-used, with more diversity and urban design quality in terms of buildings, facilities and landscapes. They have an area of polarization and attractiveness expanded on the city-region and are based on the knowledge economy. They produce new high-technology services and creative products and innovation spillovers in the city. Creativity, design, architecture and high technology services are fundamental features of these new areas of creative city. Evans (2009) suggests how these features are not necessarily exclusive of each typology of quarter but often cultural and creative features are present in the same creative and cultural cluster which develops a multi-dimensional identity and multi-functional uses. Wynne (1992) identifies the emergence and the rise of cultural quarters as geographical spaces that contain the highest concentration of culture, creativity and entertainment in a city or town, in terms of cultural clustering and concentration of networks of actors linked to the cultural and creativity field. We can argue that the cultural quarters and creative quarters are the product of interactions between urbanization, culture and creativity, especially if we pay attention to the role of networking activities and clustering process in specific urban areas. This kind of issue means two things. The first one is that the consideration of culture is important and plays a focal role on structuring urban policies and local development. The second one is that every quarter represents a characteristic area which has to structure and preserve its territorial identity.

\section{Cultural District, Economic Change and Creativity: An Integrated Approach for a Territorial Regeneration}

The aim of this article is to take in consideration the issue that the culture is a focal attribute of territorial renaissance of Raval and Mile End. The cultural paradigm is a tool which re-defines the significance of place in terms of identity, territoriality and functionality. A large number of experts have studied creative cities from different perspectives and dimensions, producing debates and new visions regarding this phenomenon. Florida (2002) has conceptualized the nature of the creative city, contributing to the debate with academics and policy makers. Sacco and Tavano Blessi (2005b) suggest an approach of development based on evolved cultural districts models, by which the creative perspective highlights the driving forces of relational and organizational spaces linked with local assets and competitive factors of innovation.

The creativity represents and contains a multilayered process of accumulation and concentration of skills, forces and energies in the city, giving to urban spaces the chance of a real change of functions and identity (Scott, 2006) (Figure 1).

The approach elaborated by Italians (Becattini, 1991; Santagata, 2002), refers to the capability to activate a strategy of renewal and re-launch a territory in terms of evolved cultural district as a policy tool for elaborating and supporting strategies of development in urban and rural regions.

The evolved cultural district approach, as a strategic tool of development and planning, fosters a model of territorial interactions and socio-creative synergy among plural actors locally based. Moreover, it defines a space of governance where local economies and territorial forces play a role of socio-economic innovations for developing a strategy of regeneration. The urban space is the privileged space of interactions where driving networking forces support and boost common synergies among local players (Becattini, 1991; Viard, 1994; Santagata, 2002a). Therefore, creative and cultural sectors and high-tech industries play a linking role among actors, clusters and locally based communities, for implementing innovation and for encouraging cohesion processes within the fragmented districts. Thus, creativity and innovation, in terms of cultural quarters and knowledge clustering spaces, address policy makers to re-think urban areas and their levels of governance (Sassen, 1991; Veltz, 1996; Glaeser, 1999; Tremblay, Klein and Fontan, 2009; Klein, Tremblay and Bussières, 2008). Therefore, creativity is not the final product but it represents the driving process of urban change (Tremblay and Cecilli, 2009). Creativity drives the urban transformation, in some cases not all, and gives to the territory the innovation framework of modern changes elaborated by local players, social communities and decisional makers (Note 1) (Landry, 2000; Scott, 2006; Storper and Scott, 2009; Tremblay and Tremblay, 2010).

\subsection{Method of Research}

This study employs an interdisciplinary systemic approach that involves geographical and spatial prospective in order to understand the complexity of the urban phenomenon and its multiple dimensions (Bertalanffy, 1971). In 
particular the geographical analysis allows us to understand the urban system in its holistic, global and post-modern dimensions (Harvey, 1990), without neglecting the goals and the main objectives of an analysis that focuses on the city as a complex dynamic urban milieu (Vallega, 1995). This research uses a number of different explorative methods which include 22 semi-structured and 3 phone interviews and an analysis of documentary sources. Semi-structured face-to-face interviews were conducted with managers (artistic and operative directors), workers and local authorities involved in the governance of the areas (public bodies and industry representatives). We obtained information from municipal reports, scholarly publications, newspapers articles and studies undertaken by different institutions. The systemic approach makes it possible to integrate this and to analyze the city as an open territorial system, in which a number of actors organize, plan and establish institutional and social relations in the systemic region for spatial organization (Giddens, 1987).

\subsection{Why Barcelona and Montreal?}

A few elements can show that Barcelona and Montréal are significant creative-cultural cities that are going through a process of social, territorial and economic regeneration.

Barcelona and Montréal are going through a process of functional, economic and social regeneration based on the knowledge economy (Ajuntament de Barcelona, 2000; DD-AA 2003; Ville de Montréal, 2003; Stolarick and Florida, 2006; Pilati and Tremblay, 2007) In both cities urban and cultural developing master plans are extremely interconnected (Ville de Montréal, 2005; Pilati and Tremblay, 2008; Brault, 2010).

The central and neuralgic areas of first regeneration (Barceloneta, Vila Olimpica, Montjuic, Diagonal, Art District (QDS) and Old Montreal are the base of an overall regeneration of the whole degraded industrial areas, considered as "creative dismissing areas" (Sacco, 2006).

Their respective metropolitan areas represent a complex urban territory and diversified spaces of governance made up of many different economic/creative sectors and socio-territorial actors, oriented to regenerate the urban spaces. They also redefine new local policies of integrated sustainable development (Ville de Montréal, 2007).

The urban changes in terms of spatial organization, clustering development and economic-creative functions have to support a global and integrated vision of development (Porter, 1995). The territorial cohesion is a fundamental element to achieve and consolidate the integration of different parts of the city (Dematteis and Bonavero, 1997; Camagni and Gibelli, 2002; Castells, 2004; Camagni and Maillat, 2006; Borja, 2010).

Culture and creativity are not the goals toward which it extends the action of planning, but they represent the driving forces of the territorial and economic planning process (Note 2). The definition of "Culture" both in Barcelona and Montreal is close to the elaboration of new spaces of urban governance based on cultural development.

Raval and Mile End are two industrial neighborhoods, with a high concentration of working-class population that has characterized the geographical and socio-territorial identities of these urban areas.

If the Raval district has an industrial origin with a long history of working-class neighborhood and shelter for poor and marginalized people (in fact there were several hospitals and religious buildings); the Mile End district is characterized by the largest textile industries located along the railroad and interconnected with the city and the port.

Both neighborhoods are experiencing gentrification processes determined by a regeneration policy aimed at urban redevelopment of lands. A process that if not controlled could lead to the expulsion of the ancient inhabitants and residents in favor of new social categories, causing negative effects on the cost of housing and use of public land for private interests.

The concept of gentrification refers to the issue that if on the one hand the process of regeneration of an urban district determines the improvement and gentrification of a specific neighborhood, on the other hand it leads to the expulsion of the usual inhabitants in favor of new rich arrivals. As for the Raval some studies have concluded that there is a process of gentrification, but we cannot verify a generalized process of population replacement, understood as the expulsion of the poor people with a massive entry of new inhabitants of the middle class. Nevertheless, there is a process of gentrification in the Raval district, as demonstrated by the high rate of new activities related to cultural and artistic services, to new activities that attract people from outside connected to the great cultural centers, museums and education structures. We can affirm that the gentrification process is touching the Raval in terms of land use and housing costs linked to the richest social classes, but at the same time we are witnessing the arrival of a new immigrant population from developing countries, without a real expulsion of the ancient inhabitants. With regard to the Mile End, the gentrification process is already underway. There are private interests and fast dynamics that are rapidly transforming the neighborhood with the 
construction of new residential real estate buildings and private parks, attracting people who are rather wealthy, although many artists are still present. This phenomenon is leading to the expulsions of residents toward other suburbs and neighborhoods of Montreal (Rosemont, Parc Extension, Verdun), perverting the urban identity of this ancient district. This process could be controlled only if public actors are able to quickly find solutions to this trend through urban regeneration policies which give a priority to social and cultural development, public spaces and collective use of lands. With this in mind, many citizens and associations are involved in the consultation and dialogue between public and private interests in order to stop the negative effects of gentrification.

An interesting report has been produced by Barcelona City Council and it defines Barcelona as "Ciutat del Conoixement" (Ayuntamiento de Barcelona, 2000). It highlights that the urban changes of the metropolis and its new cultural identity are based on knowledge economy. The analysis is very interesting because it takes into account the global strategy elaborated by the local actors and institutions.

Joan Clos, the ancient city councilor, has said: "The Knowledge City is our city, but it will be better, more powerful, more connected with the world. It is the city that changes the ancient industrial axes with new bits and new neurons of learning revolution. Barcelona is an intelligent city, rich of ideas and capacities which will help to achieve a better quality of life for all its citizens" (Ajuntamient de Barcelona, 2000, p.1).

Therefore, we find very interesting how Barcelona's institutions have fostered this process of transformation as they have understood how the global society is changing and what kind of effects are produced in local metropolitan regions. The knowledge economy produces a new city in which new spaces of governances are building an innovative urbanization. As some authors have observed, the process of governance represents the key element of change, because it defines a common platform/space of regulation (Benko and Lipietz, 1992; Feldman 1994; Pratt, 2000; Daviet, 2005) that could assess socio-territorial innovations linking territorial growth, new social identities and innovative sectors of production (Fontan, Klein, and Tremblay, 2005). Barcelona represents the metropolis of knowledge economy in Europe and it is interesting to demonstrate how creativity and culture are factors of neighborhoods change (Castells and Hall, 1994; Castells, 2004).

\section{Creative Clustering Process and Cultural Quarters: A Strategy of Regeneration}

We begin the analysis of the cultural quarters by some general points:

Defining the meaning of cultural quarter (creative and artistic identity).

Analyzing the governance and policy of cultural quarters (Raval and Mile End).

Describing the functional and economic organization of these quarters embedded in the city.

We know how cultural clusters can be potential drivers of urban regeneration processes. Therefore, the urban policies adopted by Barcelona and Montréal's Local Governments, aim to foster cultural and artistic clusters based on the reconversion of industrial neighborhoods (Ajuntament de Barcelona, 2000). In fact, given the decline of the industrial production system and the boost of tertiary activities, a source of creativity, innovation and qualitative growth in urban contexts has been identified in cultural and creative industries. Scott (2004) underlines the strategic role of creativity and innovation for developing metropolitan areas and identifies the factors of emerging cultural clusters in particular fragmented zones. A first approach has been developed during the last 15 years, according to the process of socio-economic networking and territorial clustering in some European cities such as London, Manchester, Glasgow, Dublin, Rotterdam and Berlin. A first definition of cultural quarters has been formulated by London Local Government (DCMS, 1998); it was enriched by the Greater London Authority (GLA) and by the Mayor of London:

"Cultural quarters must be developed as a key contributor to London's creative capital and the development of the broader economy, in order that achieving a better balance between the cultural facilities of inner and outer London can go some way towards reducing the social and economic inequalities between different parts of the city" and "support the development of cultural quarters and promote their role in regeneration, encouraging creative industry developments in the Thames Gateway region" (Greater London Authority, 2004b, p. 142). Since the early 90 's, the cultural regeneration approach has emerged as a strategy for urban and territorial development in many depressed areas and marginal spaces. The strategic role of public actors has been fundamental to the planning policy of creative and cultural clusters, both in terms of financing and supporting the projects, and for supervising and managing the territorial development (DCMS, 1999; Scott, 2004).The strategies formulated by local stakeholders are the pivots of regeneration of industrial and depressed quarters, as they consider interests and goals with a participative and multidimensional approach (McCarthy, 2006). They highlight the difference between culture led regeneration and cultural regeneration approaches. "Culture-led 
regeneration" requires the use of cultural activity as the principal asset and driver of regeneration, while "cultural regeneration" involves the integration of cultural activity into a broader strategy of development, where different elements build and plan an integrated process of renewal. The first approach identifies the contemporary strategy to define "cultural quarters" as spatially limited and distinct clustering areas that represent a polarization of cultural facilities and uses. In this case, we can consider a critical mass of actors and identities that form a specific space-platform of territorial complementarities and synergies and contribute to support the emergence of a cultural cluster in terms of agglomerated economies based on culture and creativity. This is the perspective we have considered in this research. It is very interesting to underline that one of the principal goals of regeneration strategy oriented by the cultural district approach is to encourage and support the synergies between socio-economic actors and local communities, in order to elaborate an integrated outline of complementarities (Sacco and Ferilli, 2006). These new cultural clusters (Raval, El Borne in Barcelona, Mile End and Plateau in Montreal and Pigneto, Testaccio-Ostiense, San Lorenzo in Rome) are embedded in cultural and artistic quarters, geographically limited. They polarize cultural activities and creative performances between creative and economic actors, for encouraging and implementing "territorial synergies" (Santagata, 2004).

The aim is to create a system of cultural quarters: an integrated polycentrism of cultural and techno-creative neighborhoods. In this way, the cluster of Plaça des Angels (core of Raval) and the emerging cluster in Mile End could represent a leading project/space founded on the cultural quarter for encouraging regeneration of marginalized central areas. The objective of this research is to clarify how this process of revitalization takes place, analyzing the role of local actors in the process of governance. We have taken into account theories on new cultural regeneration approaches (Scott, 1997; DDAA 1999; Mommaas, 2004; Sacco, 2006; Scott 2006; Evans, 2009) as well as the latest researches on cultural clusters and cultural districts with an integrative perspective (Tremblay, Klein and Fontan 2009). We can thus define cultural quarters as:

Relational and organizational spaces of participation/debate/practices between local institutions and citizens (Sacco, 2006).

Local districts of innovation and social regeneration (Evans, 2009; Roodhouse, 2009).

Micro-cultural "cities" and artistic quarters with special identity and sense of territoriality (Evans, 2004a). A territorial concentration of cultural and artistic activities and facilities based on creativity (Fig. 2)

\section{The Raval-lab: The Role of Actors between Planning and Renewal as "Barrio Laboratorio"}

The case of Raval in Barcelona is very emblematic because it aims to regenerate a central quarter while involving the local community which has been defined as holding a distinctive characteristic of "ravaleja". El Raval is a neighborhood embedded in the ancient Ciutat Vella District (Fig. 3). The neighborhood, especially the part closest to the port, is also informally known as "Barri xinès" or "Barrio chino" with particular reference to the ancient meaning of marginalized, poor and depressed area populated by lower classes. El Raval is one of the two historical neighborhoods that border the Rambla (the other is the Barri Gòtic). El Raval has changed significantly recently; due to its central location, it has become an area of attraction in Barcelona (Fig. 4). The Raval is witnessing an interesting change in terms of population. Many immigrants have chosen El Raval to live, from Pakistanis and Indonesians, to a more recent Eastern European community, especially from Romania. Immigration represents an important phenomenon which is transforming the territorial and cultural identity. We can affirm that a high part of residents and inhabitants of Raval (47\%) inside the Ciutat Vella District came from abroad (40,5\%), as well they build a new framework of social identities in this neighborhood which is considered one of the most multicultural quarters in Europe, considering the range of resident-immigrants and total resident in the Ciutat Vella. We can see that the Ciutat Vella District has increased between 2001-2010 resident-immigrants (from $18,2 \%$ to $40,5 \%$ ) considering the percentage of total resident of each district, in comparison with other central and external districts of Barcelona (Exaimple, Saint-Montjuic, Les Corts). However, if we consider the relation between the Ciutat Vella District and Barcelona metropolitan area, we can highlight how central neighborhoods (El Raval, El Borne, La Rivera, Barrio Gotico) are losing resident-immigrants because the process of gentrification is producing the sprawling of its population over the suburbs (21\% in 2001 to $14,5 \%$ in 2010) (Table 1; Table 2). This cultural and territorial identity is the product of social construction and territorial processes (Lefebvre, 1974). However, if we consider Raval and Mile-End in a comparative study, it is important to analyze three factors of socio-spatial organization:

1) How the process of regeneration leads to define a critical mass and artistic atmosphere to a real cultural quarters in terms of clustering organization.

2) What is the role of actors outlining different cultural clusters in the Raval and Mile End. 
3) What kind of effects in terms of spatial and social changes we can observe regarding art clustering development and art buildings polarization in the two neighborhoods.

Both in Raval and in Mile-End, we can identify a huge concentration of cultural activities and creative capital that encourage the growth of local communities which play a key role for developing local economies and supporting regeneration master plans through spontaneous and institutional strategies (Rius and Subirats, 2005; Rius and Rodriguez Moratò 2006).

The CCCB Director, during an interview, affirms: "I think that the most important topic and challenge in the Raval, considering the cultural regeneration as new local framework, is represented by the strong and intensive process of immigration. It is a new immigration that is changing the neighborhood; it represents the new important issue for Raval, for territorial development, a social identity and a local creativity. We must understand that Barcelona is changing fast and that Raval represents the most important area of transformation in the city....The CCCB is the center of art and creativity of the city's changes, so we should consider the new territorialization process as an important element of research and debate for our productions and experiences. We cannot ignore it."

El Raval seems to characterize the emergence of cultural and creative quarters, in which different actors play a fundamental role of transforming a depressed area into a new cultural cluster (DDAA-Ajuntament de Barcelona, 1997; DDAA-Ajuntament de Barcelona, 2003; Districte de Ciutat Vella, 2003; Delgado Ruiz, 2007; Subirats and Rius, 2008). Although, we can observe an intensive clustering concentration in the Raval, it may be interesting to clarify the authentic role of actors in the area and the ranking of connections of the cluster (Porter, 1998). Sacco suggests (2006) the concept of "incremental cultural cluster" because this approach defines not simply a physical agglomeration of cultural facilities concentrated in Plaça des Angels, but also because it describes the dynamic processes of development, according to organizational networking system among different players (Sacco and Ferilli, 2006, Scott, 2006; Paiola, 2008).

The main objective has been to develop innovation and growth through major urban, artistic and architectural projects, with the aim to achieve the development of degraded industrial areas like El Raval, El Borne, Barceloneta, Vila Olimpica, Diagonal, 22@, PobleNou. As an artist director says" The goal is to transform Barcelona into an international platform-hub of knowledge in which local and global networks will be able to lead and exchange knowledge, savoir-faire and innovation. My task, as expert of art and creation environments, is to create and stimulate networks of locally based creative networks in order to promote art and business in my community and in my neighborhood, El Raval... where I work." It is important to mention that the MACBA and the CCCB (Barcelona Museum of Contemporary Art and the Centre for Contemporary Culture in Barcelona) are examples of a first regeneration of Raval, and they represent deep changes in economic dynamics and socio-cultural features of CiutaVella's district. As some Catalan scholars write: "The raising cultural cluster of Raval embedded in the Angels Square is the main positive aspect of reforming and change process of this quarter" (Subirats and Rius, 2008, p.97). Although this cultural cluster has been founded and planned (at first stage) by top-down policies, in order to build the pole MACBA-CCCB. These art-centers have become creative incubators and spaces of experimentation. They influence the whole Catalan cultural context (Subirats and Rius, 2008; Fundacio Kreanta, 2010). Raval is the quarter where multi-faceted features of multiple dimensions (social, cultural, territorial, environmental and economic dimensions) define a model of development based on the uniqueness of urban and socio-cultural characters. "El Raval" could be defined as a district-laboratory, the so-called Raval-LAB.

We have interviewed a member of an Association called "Arquitecturas Colectivas" which has been working for the Raval District and for Barcelona Council, restoring old industrial areas like Barceloneta. The interviewee says "We have to redefine the principles and values of regeneration and urban planning... we cannot think to formulate an integral requalification (talking about Barcelona and Raval) without taking into consideration the active participation of citizens...it is a strategy that is not conform with the reality. The governance as an associative process of management, planning and operation, is the key factor to achieve a qualitative and sustainable development". The action of groups, collectives and associations is strong and cohesive in the Raval. In fact, the civic association Tot-Raval is becoming a fundamental actor of coordinating and planning socio-economic initiatives in order to encourage the development of the district. It combines and links the different identities for achieving the community's targets (Ajuntament de Barcelona, 2000; Districte de Ciutat Vella, 2002; Focivesa, 2003; Mascarell, 2008). This combination of strategic tools and approaches in terms of top-down and bottom-up levels of urban policies represents and symbolizes the relationship between local development processes (Raval) and global dynamics of metropolitan growth (Barcelona) (Diputacio' de Barcelona, 2000; Borja, 2003; Subirats and Rius, 2008). Raval-urban laboratory is the core and the 
meeting-networking space. It represents a geo-spatial and socio-cultural laboratory of experiments and convergences of cultures and territories.

Some characteristics should be emphasized in order to understand the dynamics of the neighborhood, its history, its evolution and the current socio-territorial practices of organization. First of all:

Raval is an old neighborhood with a strong religious presence in terms of structures and institutions.

Raval has a strong identity among industrial workers, since it has been a working-class neighborhood close to the port, having many factories, abandoned buildings and obsolete industrial complexes.

Raval has dynamically lived through progressive functional decline, which came as the result of the de-industrialization process, causing extensive degradation to the social, economic and territorial framework.

Raval is a ghetto in the city center, with a history of social and territorial conflicts.

It occupies a geographical and functional centrality in Barcelona.

Same current changes within the composition of Raval include:

A general strategy of urban regeneration.

A social and cultural regeneration (infrastructure, training, education, participation).

The definition of El Raval district as a laboratory and a meeting place of multi-ethnic groups.

A new urban center for culture and creativity in Barcelona.

An ongoing process of transforming the neighborhood into a truly evolved cultural district, according to the paradigm of the concentration-production diffusion of artistic and cultural products and services in favor of a complex economic and social regeneration.

Raval is witnessing an intense activity of renovation as well as architectural and urban regeneration. The most obvious example is the Rambla del Raval.

Raval represents an international platform for creativity in Barcelona.

Considering the main urban transformations that have involved the Raval, it is important to characterize the framework of global change in the district of CiutatVella (1988-2005). We could summarize this change in some significant points of requalification:

Urban renovation has involved some 500 buildings and 4.500 homes, of which $20 \%$ were empty. Some $110.000 \mathrm{mq}$ of occupied land have been transformed into public space (61\%), facilities $(15 \%)$ and housing $(24 \%)$.

Some 3.100 new public subsidies homes have been built, 600 through complete restoration.

With the grants for private rehabilitation, 3.109 buildings have been improved, accounting for around $53 \%$ of the private buildings in Ciutat Vella.

CiutatVella has gained a new infrastructure: the pneumatic solid waste collection network. There are 2.420 meters of underground network and two collection centers in Santa Caterina and Raval.

The CiutatVella neighborhoods have been equipped with over 40 new facilities, such as libraries, civic centers, social and personal services centers, schools, nurseries, residences and home for elderly people.

The investment made by the public administrations, up to the 2005 financial year, in the Ciutat Vella transformation and revitalization process has exceeded 1.300 million euros.

The PERI of Raval ("Plan Especial de Reforma Integral"-Special Plan) was divided into 4 main aspects.

a) Reforming $10 \%$ of the total area of the district in reference to land use (public spaces, green areas, infrastructure).

b) Demolishing expropriate and the most degraded buildings in order to produce collective uses of space, rebuild public buildings and residences of social housing in the neighborhood, providing new cultural and social facilities.

c) Rehabilitating the urban lands degraded through joint action by public and private stakeholders.

d) Targeting early intervention in the northern part of the Raval and then towards the center, building a large central square and big public spaces. 
When we asked about the important role of actors, the Director of Tot-Raval Foundation says "It is very important to identify and meet all the local actors in the quarter and boost them to participate in the governance process and the development strategy ...we must encourage the process to foster the plurality and the different features of the quarter and involve the local communities into the regeneration process...we must walk together if we want to achieve our objectives. This is the reason why I have said that there are many Ravals in the Raval. We have people who live here since 1920-1930. We can meet people who arrive in the area from everywhere and in different periods, an intensive immigration process. We have arrivals related to the gentrification process that constitute an important social dimension of Raval (artists, actors, students, professor and managers) who are attracted by the quality of life and the artistic atmosphere. It is very important to observe and communicate with all of them, and the Tot-Raval Foundation enhances the communication and the debate to achieve common goals, this is our first priority. In the Raval we have a kind of melting-pot and multicultural atmosphere: we have a kind of co-existence, but it is not a form of integration....so the participation and empowerment of local groups, municipal committees and associations is the most important thing for generating common processes of development (procesos comunitarios de desarrollo cultural)".

Also, when asked if Raval is an emerging cultural area, she replied that it is true. "We can consider Raval as a real cultural quarter formed by two different levels of culture. The first level based on the macro-culture (MACBA, CCCB, FAD, and UB) and the second level composed by small and medium associations, galleries and studios that we must represent and link together in order to solve problems and conflicts and to stimulate the complementarities...el barrio is a cultural production industry; the territory is a fabric of artistic and creative production. Raval's experience represents the transformation of the industrial quarter into Raval-Laboratorio and considering it, not only as a territorial experience but also like a concept for development...we have to appreciate Raval as a real quarter through which is developing a new sign of innovation and creativity, like a neuron in Barcelona that can expand and reproduce itself". According to the cultural district approach applied to the field of culture and territory (Sacco, 2006), Raval would be considered as a model of evolved cultural district.

The concept of a cultural district emerges with Marshall's "industrial district" and later, as an innovative cultural driving strategy for regenerating and developing territories (Becattini, 1991; Santagata 2002; Hutton, 2004; Santagata, 2004; Markusen, 2006; Bagwell, 2008). Furthermore, some scholars have analyzed the cultural district approach with new researches based on socio-territorial innovations (Santagata 2002a; Sacco and Pedrini, 2005; Sacco 2006; Tremblay and Tremblay, 2006; Tremblay and Pilati, 2008). Following these works and combining the approaches, Raval represents an interesting case, regarding the territory as new space of regulation among plural actors involved in the cultural regeneration process.

Raval's neighborhood, as emerging evolved cultural district, has its core in the clustered system located in Plaça des Angels: a multi-dimensional space, an artistic and creative production centrality of innovation polarized in MACBA-CCCB's pole. Definitely, the cluster is the pivot of an urban policy aiming to transform Raval and its socio-organizational system. The clustering process has its main element of experimentation and challenge in the CCCB (Note 3).

\section{The Neighborhood of Mile End: An Inclusive and Polycentric Approach for the Territory}

In Montreal, Mile-End is changing its territorial identity. It used to be an old industrial area populated by workers embedded in the ancient Plateau-Mont Royal district (fig. 4). The nature of changes is both spontaneous (bottom-up dimension) and voluntary inasmuch as it is supported by local and municipal institutions (top-down dimension). Mile End is becoming a cultural quarter in which the agglomeration processes of creative activities are associated with the local dynamics of concentration of creative firms. The same process has occurred in the district of Hoxton-South Shoreditch (SoSho) in Northern London, where after the presence of artists and art schools, the district has undergone a transformation of economic and social fabric.

We can consider that the emerging creative cluster of Mile End represents the key factor of cultural and creative regeneration and it involves many different economic sectors interconnected by complementarities in terms of networks, new business connections and potential partnerships (ex. Ubisoft and artist-run centers). Mile End is a creative polycentric cluster with a mix of uses and activities which are based on flexible specialization (Scott, 2006). It consists of formal and informal socio-economic actors, often recognized by artistic presences which contribute to the economic development of the area. "Formal" groups and "informal" groups of artists and artist-run centers like Diagonale, AgenceTopo, Centre Clark, Articule, Galerie and Atelier Circulaire have a strong presence and reputation in the district, according to the creative networks where active local players take part in the processes of governance. Cohendet (2010, p. 92), describing the creative atmosphere in Montreal and 
its levels of creativity, writes "in between the upperground and the underground, we suggest that a key role is played in the creative city by the middleground, which is the level where the work of communities is decisive in designing the grammars of use and other common platforms of knowledge necessary for the knowledge transmission and learning that precedes innovation in those geographically bounded innovative environments".

Regarding Mile End, we identified the main elements that are transforming this area:

The revitalization of the urban economic space and the concentration of innovative and creative firms lead to new cultural clusters embedded into the Saint Viateur area.

The high level of flexibility and specialization of local firms and multimedia industry provides exchanges between artists and firms.

The configuration of cultural/artistic areas as spaces "of multiple belongings", traditionally open and tolerant (Hutton, 2006).

A large participation of inhabitants and citizens in the elaboration of creative and cultural strategies of regeneration.

The regeneration process is more spontaneous than institutionalized.

A recent process of gentrification that is transforming the neighborhood; although we can say that artists are still present, the arrival of the gaming firm Ubisoft has to a certain extent changed the neighborhood. The private sector has thus indirectly contributed to the regeneration and gentrification of Mile End, as the arrival of such a large firm fostered much economic activity (restaurants, cafés) and attracted creative workers to this district.

Regarding the empirical analysis, we can observe specific characteristics which define the territorial identities of Raval and Mile-End in order to evaluate the role of socio-economic actors in planning and structuring the area and to analyze the level and intensity of relations. The level of international branding of institutions also plays a key role for boosting local development and for encouraging their strategic goals (Note 4). The following analysis highlights some specific features which define the processes of cultural regeneration in the Raval and in the Mile End (table 3).

It is important to note that the respective processes of clustering development are dynamic and flexible in both neighborhoods. Therefore, we can observe how the cultural cluster in the Raval is going through a phase of consolidation and a new orientation towards an evolved cultural district model (Sacco, 2006). However, in Mile-End, the organizational process of territorial regeneration has been consolidated in terms of social identity and creative networking production system, classifying Mile-End and Plateau as the first cultural quarters in Quebec and Canada (Hill Strategy Research, 2010). The clustering process is emerging around creative firms and innovative working spaces like Ubisoft that attract artistic and cultural players in the neighborhood.

\section{Mile End as a Space of Creativity and Cultural Development: The Pole Saint-Viateur Est}

In this comparative study, we can observe that the processes of territorial regeneration are supported and implemented through spontaneous changes and socio-economic factors which have determined the concentration of artists, galleries and artistic studios in the old industrial buildings localized in the area of Saint-Viateur Est. They are embedded in old manufacturing factories. The process of agglomeration of artists into the manufacturing and multi-functional open-spaces is intensive and is related to the efforts of a formal and an informal system of creative firms, polarized in a local geographical milieu. Some artists and art managers who live and work in this neighborhood talk about this rapid transformation and they say "we would like to increase the art market, linking art-production and art-products with workshops and exhibitions". Moreover, during the interviews, when we talked about the nature of change, they suggested "we are happy about the new nature of Mile End, a quarter that represents the biggest concentration of artists and creators in Montreal and Canada...It is unbelievable! We have only in this sector...Saint-Viateur sector ... more than 500 artists...it is huge!!"

During the interviews the main factors of attractiveness that were identified are:

Open and comfortable spaces of work in old industrial buildings.

Low prices of studios.

Stimulating atmosphere and networking relations between artists and creators

Proximity and concentration between various sectors of Mile End and other zones, such as Rosemont.

Quality of life and good facilities in the area, mostly because of the centrality of Mile End in Montreal. 
The intensive gentrification process that has forced a kind of exodus from the ancient industrial areas located in downtown (Place des Arts, Vieux Port and Boulevard Saint Laurent).

More precisely, creative firms and artistic studios in this cultural pole tend to adopt a very particular organization withthe sector Saint-Viateur Est, as point of reference for the entire neighborhood. Today, it represents a real functional pole of art production and creativity in Montreal. An important role of supporting and financing artists and creative firms has also been assumed by Ubisoft.

Ubisoft, a multimedia firm, plays a key role for developing local dynamics of networking between different entities and groups interested in the regeneration of Mile End. As the Director of Communication say, the role of Ubisoft has been strategic in supporting and financing cultural projects in the area: "Ubisoft has an important effect in the nature and in the morphology of Mile End, mostly in terms of economic changes and cultural perspective of development. We have participated actively in art performances organized in the quarter and we have supported initiatives like Ateliers Portes Ouvertes, where artists and creators have been financed by Ubisoft. Nevertheless, we have expressed our will to support and protect the lofts and the studios where the artists produce and distribute their production...we can play a role of conciliation and mediation but we can't have a role of negotiation...we are always a private firm and we have our economic interests...Therefore, the prices and the accessibility were important factors of localization without a special strategy at the beginning...after, a creative atmosphere has developed cumulative effects in the territory". Furthermore, the cultural development adviser of CDEC Plateau-Mont Royal, suggests how it is important to support and foster the creativity production and the artistic life in Mile End: "The role of the CDEC is to endorse and support the activities of artists who work and produce in Mile End. The CDEC is an institution which has the role to coordinate and arrange various local actors with the aims to find common strategies and to foster a process of collective development by empowerment strategies. The CDEC has the task of listening to the different instances and to seek mediation and a common trajectory among different actors like the City of Montreal, the Plateau district, the communities of artists and associations of citizens who live and work in the neighborhood. Certainly, the attention has been focused around the area of Saint Viateur-Est because in this territory the de-industrialization process has generated great chances and advantages of development and regeneration. ....An important role was played by a new association called P2 (Pied Carré), because it is a kind of lobby and group of artists (managed and governed by artists and created in 2009) which supports and encourages the artists' claims and their active practices toward the local institutions".

Thus, other associations are growing up for supporting and implementing the artistic life in the area of Saint Viateur Est. A member of P2 association was interviewed during this research on Mile End and she says "the process of production and creation by artists in the Mile End is intensive but we need to find a way for developing the neighborhood and anchoring the artists and the production activity in the area as well as involving local communities and associations into the process of creative production. We need to prevent the process of gentrification and, furthermore, minimize the action of investors of the real estate market to avoid the depletion of the district. The district of Mile End is ultimately a reflection of the shock caused in the central artistic area of Montreal (Quartier des Spectacles), where an action planned and managed by the institutions has led to the exodus of artists. We have to achieve another objective for the pole Saint-Viateur and it consists in recognizing and institutionalizing the work of artists run-centers. Thus, the city should manage and regulate their activity, spaces and should support and finance the associations of creators and artists."

In any case, the key element is the ability to acquire and manage industrial space through a business plan for the protection of rents or to facilitate purchasing bythe artists. The owners of the buildings should have a plan for protecting the artists. The director of an artist run-center says "we must form a true coalition and partership to increase the cultural production and support the creativity. The bottom-up level of revitalization leads to a joint-process of transformation of the district, involving local community organizations, associations, groups of self-managed artists, volunteers and CDEC which has the role of coordinating and supporting collective action...Thus it is possible to embed the artists in their spaces and preserve the Mile End from an additional and incoherent redevelopment caused by a residential property portfolio, which would deprive the district of his original identity". With their exhibitions, special projects, conferences, training programs and their artistic residencies, the artist run centers are embedded in the industrial blocks of Mile End. Art proposals are received annually and selected for the quality and originality of their research and artistic expression, as well as their contribution to the advancement of contemporary art practices. They became a cultural reference and a site for research, production and dissemination of contemporary art at regional, national and international levels. They organize conferences (Agence Topo, Clark, Atelier Circulaire, Articule) and workshops around specific themes proposed by exhibiting members or resident artists. They also work as a web production laboratory that invites 
the artistic community to rethink the space within the context of cyberspace. There are networking platforms that offer various services pertaining to dissemination, promotion and training. One of the targets is to make their members' practices better-know, circulate their works, increase their visibility on the national and international scene and promote sales. The artistic run centers represent local models of cultural regeneration as well as spatial entities for innovative and creative performances.

\section{Conclusion}

This comparative study analyzed some characteristics of cultural and territorial regeneration according to the consolidated (Raval) or emerging cultural districts (Mile End) which represent urban changes in the post-modern society and in the urban dimension based on the creativity and innovation. The Raval and Mile End are two emblematic cases of metropolitan central spaces which have been transformed and revitalized in order to regenerate industrial zones and transform obsolete buildings and dismissed spaces into new spaces of creative production (fig. 5). Barcelona and Montreal are playing the role of regional poles of creative production and new cultural regeneration based both on urban planning development and on advanced cultural policies. Thus, we can consider the models of cultural cluster (Mile End) and cultural district (Raval) as outlines in order to elaborate a significant operational strategy both in the Mile End, where the process of clustering is emerging, as well as in the Raval where the clustering dynamics are consolidated. As was shown by our two cases, there is an interesting dynamic of participation of the private and public sector in both cases of urban regeneration.

On the one hand, El Raval has consolidated its clustering dimension as well as its territorial configuration of cultural centrality, but is still building a new networking and clustering synergy based on the evolved cultural district in which local actors play a role in co-operation and collaboration to achieve an integrated cultural change. The synergy between local stakeholders and the community is a fundamental factor in order to develop an evolved cultural district as well as to increase creative models of territorial development. El Raval is the best example in Barcelona.

On the other, Mile End is an emerging cultural pole embedded in old industrial buildings and identified with the artist run centers. In this case the process of regeneration is induced by spontaneous dynamics and governed through a bottom-up approach by local actors. Thus, the regeneration approach represents an interesting turn in urban cultural policy-making. We are witnessing a change of policies from an exclusive, closed, and vertical dimension of cultural experience into a much more inclusive, synergic and horizontal strategy of development. These dynamics are structuring these creative territories, regarding "El Raval" as Catalan model of cultural neighborhood and Mile End as a creative emerging territory in Montreal.

To conclude, if we suggest a kind of definition and purpose for a cultural quarter according to Raval and Mile End, we could highlight some characteristics which define the regeneration processes of these quarters (table n. 4). A cultural quarter would be identified and planned: (i) to improve the regeneration of a geographical area; (ii) to concentrate, as a physical and creative hub, cultural, social, and economic activities; (iii) to act as a catalyst of production and consumption of cultural services; (iv) to encourage the participation of local communities; (v) to support and maintain artists' galleries and studios, as well as preserve the quarter (Raval and Mile End) from intensive gentrification and real estate interests; (vi) to improve the quality of life for workers and citizens who live in the quarter; (vii) to reinforce the local development through the partnership between local institutions and other economic and productive sectors. We can see how Raval and Mile End represent cultural quarters restored by a regeneration process and they are emerging locally and internationally as new open neighborhoods, symbols of participation and accessibility. They represent new creative spaces in old industrial marginalized areas as well as potential quarters of sustainable development based on culture considered as a series of symbols, representations and values produced by local communities. Finally, Raval and Mile End represent two examples for developing cultural quarters as well as they could define new territorial models for integrated strategies of regeneration where the local communities are involved actively in the processes of governance and development. They represent two territorial and cultural experiences based on clustering processes of creative firms, local institutions and creative industry that demonstrate different dimensions of collaboration and exchange among local stakeholders which play a fundamental role of planning in a context of open governance. One of the main challenges of these zones remains to achieve socio-economic development and cultural growth while fostering a social and a sustainable development in order to create a new urban centrality in the old and marginalized areas.

\section{References}

Ajuntamient de Barcelona. (2000). Barcelona: Ciutat del Coneixement.. Barcelona Metropolis Mediterranea, 1, Barcelona.

Ayuntamiento de Barcelona. (2000). El futur desenvolupament de les industries de cotinguts d'informacio' de la ciutat de Barcelona. Barcelona. 
Bagwell, S. (2008). Creative cluster and city growth. Creative Industries Journal, 1(1), 31-46. http://dx.doi.org/10.1386/cij.1.1.31_1

Becattini, G. (1991). Italian districts: problems and perspectives. International Studies of Management and Organization, 21(1), 83-90.

Benko, G., \& Lipietz, A. (dir.). (1992). Les régions qui gagnent. Districts et réseaux : les nouveaux paradigmes de la géographie économique. Paris: PUF.

Bertalanffy, J. (1971). Teoria generale dei sistemi. Milano: Mondadori.

Borja, J. (2003). La ciudad conquistada. Madrid: Alianza Editorial, S. A.

Borja, J. (2010). Luces y Sombras del Urbanismo de Barcelona. Barcelona: Ed. UOC.

Brault, S. (2010). Le facteur C. L'avenir passe par la Culture. Montréal: Les editions voix paralléles.

Camagni, R., \& Gibelli, M. (2002). Forme urbaine et mobilité. Paris: RERU n.1.

Camagni, R., \& Maillat, D. (sous la dir. De). (2006). Milieux innovateurs: théories et politiques. Paris: Economica.

Castells, M. (2004). The Network Society: A Cross-cultural Perspective. London: Edward Elgar.

Castells, M., \& Hall, P. (1994). Technopoles of the World: the Making of Twenty-first Century Industrial Complexes. London: Routledge.

Cohendet, P. (2010). The Anatomy of the Creative City. Industry and Innovation, 17(1), 91-111. http://dx.doi.org/10.1080/13662710903573869

Daviet, S. (2005). Industrie, culture, territoire. Paris: L'Harmattan.

DCMS (Department for Culture, Media and Sport), (1998). Creative industries mapping document. DCMS, London.

DDAA. (1997). Reforma y mejoradel interior de la ciudad. Barcelona: Ajuntament de Barcelona.

DDAA. (1999). Escenes del Raval. Barcelona: Centre de Cultura Contemporanea de Barcelona i Ajuntament de Barcelona.

DDAA. (2003). La Barcelona rebelde. Guia de una ciudad silenciada. Barcelona: ed. Octaedro.

DDAA. (2003). La Ciutat Vella: un passat amb futur. Barcelona: Ajuntament de Barcelona.

Delgado Ruiz, M. (2007). La ciudad mentirosa. Fraude y miseria del «modelo Barcelona. Madrid: La Piqueta.

Dematteis, G. \& Bonavero, P. (1997). Il sistema urbano italiano nello spazio unificato europeo. Milano: Il Mulino.

Department for Culture, Media and Sport. (1999). Guidance for Local Authorities on Local Cultural Strategies. DCMS, London.

Diputacio' de Barcelona. (2000). Cultura en Xarxa. La politica cultural de la Diputacio' de Barcelona. Barcelona, Diputacio de Barcelona.

District de Ciutat Vella. (2002). Memories del Districte de Ciutat Vella. Barcelona: Districte de Ciutat Vella.

District de Ciutat Vella. (2003). Pla d' actuacio' de Districte 2004-2007. Barcelona: Districte de Ciutat Vella.

Evans G. L. (2004a). Cultural industry quarters - from pre-industrial to post - industrial production, in D. Bell \& M. Jayne (eds). City of quarters: Urban Villages in the Contemporary City. (pp.72-92). Aldershot: Ashgate.

Evans, G. L. (2009). Creative cities, Creative Spaces and Urban Policy. Urban Studies, 46(5/6), 1003-1040. http://dx.doi.org/10.1177/0042098009103853

Feldman, M. (1994). The Geography of Innovation. Boston: Kluwer Academic.

Florida, R. (2002). The Rise of the Creative Class. New York: Basic Books.

Focivesa. (2003). Pla d'accio Rehabilitacio a Ciutat Vella 2002-2005. Barcelona: Foment de Ciutat Vella SA.

Fontan, J. M., Klein, J. L., \& Tremblay, D. G. (2005). Innovation socioterritoriale et reconversion économique: le cas de Montréal. Paris: L'Harmattan.

Fundacio Kreanta. (2010). Ciudades Creativas. (1). Barcelona: Ed. Kreanta. 
Giddens, A. (1987). La constitution de la société - éléments de la théorie de la structuration. Paris: Presses Universitaires de France.

Glaeser, E. L. (1999). Learning in Cities. Journal of Urban Economics, 46, 254-277. http://dx.doi.org/10.1006/juec.1998.2121

Greater London Authority. (2004b). London Plan. GLA, London.

Harvey, D. (1990). The Condition of Postmodernity: An Enquiry into the Origins of Cultural Change. Cambridge: Blackwell.

Hill Strategy Research Inc. (2010). Cartographie des artistes et des travailleurs culturels dans les grandes ville $d u$ Canada. Montréal: Hill Strategy Research Inc.

Hutton, T. A. (2004). The new economy of the inner city. Cities, 21(2), 89-108. http://dx.doi.org/10.1016/j.cities.2004.01.002

Hutton, T. A. (2006). Spatiality, built form, and creative industry development in the inner city, Environment and Planning A, 38(10), 1819-1841. http://dx.doi.org/10.1068/a37285

Klein, J. L., D. G. Tremblay \& D. Bussières. (2009). Community Based Intermediation and Social Innovation. A Case Study in Montreal's Apparel Sector. International Journal of Technology Management, 51(1), 121-138.

Landry, C. (2000). The Creative City: A Toolkit for Urban Innovators. London: Earthscan.

Lefèbvre, H. (1974). Production de l'espace. Paris: Anthropos.

Markusen, A. (2006). Urban development and the politics of a creative class: Evidence from the study of artists, Environment and Planning A, 38(10), 1921-1940. http://dx.doi.org/10.1068/a38179

Mascarell, F. (2008). Barcelona y la modernidad. La ciudad como proyecto de cultura. Barcelona: Editorial Gedisa S.A.

McCarthy, J. (2006). Regeneration of Cultural Quarters: Public Art for Place Image or Place Identity?, Journal of Urban Design, 11(2), 243-262. http://dx.doi.org/10.1080/13574800600644118

Mommaas, H. (2004). Cultural Clusters and the post industrial city: towards the remapping of urban cultural policy. Urban Studies, 41(3), 507-532. http://dx.doi.org/10.1080/0042098042000178663

Paiola, M. (2008). Cultural Events as Potential Drivers of Urban Regeneration: An Empirical Illustration. Industry and Innovation, 15(5), 513-529. http://dx.doi.org/10.1080/13662710802373916

Pilati, T. \& Tremblay, D. G. (2007). Cité creative et district culturel: une analyse des thèses en présence. Géographie, économie, societé, 9, 381-401. http://dx.doi.org/10.3166/ges.9.381-401

Pilati, T. \& Tremblay, D. G. (2008). Le développement socioéconomique de Montréal: la cité créative et la carriere artistique comme facteurs d'attraction? Canadian Journal of Regional Science, 30(3), 475-495.

Porter, M. E. (1995). The competitive advantage of the inner city. Harvard Business Review, 73(3), 55-71.

Porter, M. E. (1998). Clusters and the new economy of competition. Harvard Business Review, 76(6), 77-90.

Pratt, A. (2000). New Media. Geoforum, 31, 425-436. http://dx.doi.org/10.1016/S0016-7185(00)00011-7

Rius, J. \& Rodriguez Moratò, A. (2006). La governance cultural urbana. El cas del cluster cultural del Raval. Working paper, Centre d'Estudis de Sociologia de les Arts i la Cultura (CESAC-Universitat de Barcelona).

Rius, J. \& Subirats, J. (dir). (2005). Del Xino Al Raval. Cultura I transformaciò social a la Barcelona central. Barcelona: Centre de Cultura Contemporanea de Barcelona - Institut d'Edicionis.

Roodhouse, S. (2009). Cultural Quarters. Principles and Practice. Bristol: Intellect Books.

Sacco, P. \& Pedrini, P. (2005). Il distretto culturale: mito o opportunità?. Dipartimento di Economia, International Center for the research on the Economics of Culture, institution and creativity, 5.

Sacco, P. L. \& Ferilli, G. (2006). Il distretto culturale evoluto nell'economia post industriale. DADI, Università IUAV WP, 4 (06).

Sacco, P. L. (2006). Il distretto culturale evoluto: competenze per l'innovazione, la crescita e l'occupazione. Bologne: Goodwill.

Sacco, P. L. \& Tavano Blessi, G. (2005b). Distretto cultural e aree urbane. Economia della cultura, 15(2), 153-165. 
Santagata, W. (2002). Cultural districts, property rights and sustainable economic growth. International Journal of Urban and Regional Research, 26(1), 9-23. http://dx.doi.org/10.1111/1468-2427.00360

Santagata, W. (2002a). Cultural district, property rights and sustainable economic growth. Note of research. Turin: EBLA Center.

Santagata, W. (2004). Cultural district and economic development. Note of research. Turin: EBLA Center.

Sassen, S. (1991). The Global City: New York, London, Tokyo. Princeton: Princeton University Press.

Scott, A. J. (1997). The cultural economy of cities. International Journal of Urban and Regional Research, 21, 323-333. http://dx.doi.org/10.1111/1468-2427.00075

Scott, A. J. (2004). Cultural-products industries and urban economic development - Prospects for growth and market contestation in global context. Urban Affairs Review, 39(4), 461-490. http://dx.doi.org/10.1177/1078087403261256

Scott, A. J. (2006). Creative cities: conceptual issue and policy questions. Journal of Urban Affairs, 28(1), 1-17. http://dx.doi.org/10.1111/j.0735-2166.2006.00256.x

Stolarick, K. \& Florida, R. (2006). Creativity, connections and innovation: A study of linkages in the Montreal Region. Environment and Planning A, 38(10), 1799-1817. http://dx.doi.org/10.1068/a3874

Storper, M. \& Scott, A. J. (2009). Rethinking human capital, creativity and urban growth. Journal of Economic Geography, 9, 147-167. http://dx.doi.org/10.1093/jeg/lbn052

Subirats, J. \& Rius, J. (2008). Del Xino al Raval. Barcelona: Hacer Editorial.

Tremblay, D.-g. \& Elisa Cecilli. (2009). The Film and Audiovisual production in Montreal: challenges of relational proximity for the development of a creative cluster. The Journal of Arts Management, Law, and Society, 39(3), 157-187.

Tremblay, D. G. \& Pilati, T. (2008). Tohu and artist-run centres in Montreal: contribution to the creative city? Canadian Journal of Regional Science, 30(2), 337-356.

Tremblay, D. G. \& Tremblay, R. (dir.). (2006). La compétitivité urbaine à l'ère de la nouvelle Économie: enjeux et défis. Québec: Presses de l'Université du Québec.

Tremblay, D. G. \& Tremblay, R. (dir.). (2010). La classe créative selon Richard Florida. Un paradigme urbain plausible?. Québec: Presses de l'Université du Québec.

Tremblay, D. G., Klein, J. L., \& Fontan, J. M. (2009). Initiatives Locales et Développement Socioterritorial, Télé-université, Université du Québec à Montréal, Québec.

Vallega, A. (1995). La regione, sistema territoriale sostenibile. Compendio di geografia regionale sistematica. Milano: Mursia.

Veltz, P. (1996). Mondialisation, villes et territoires : l'économie d'archipel. Paris: Presses universitaires de France.

Viard, J. (1994). La société d'archipel ou les territoires du village global. Paris: L'Aube.

Ville de Montréal. (2003). Montréal, Ville de Savoir. Rapport du Comité Conseil Montréal Ville de Savoir. Ville de Montréal.

Ville de Montréal. (2005). Montréal, Cultural Metropolis. A Cultural Development Policy for Ville de Mntréal 2005-2015. Ville de Montréal.

Ville de Montréal. (2005).Reussir@Montréal, Stratéges de développement économique 2005-2010 de la Ville de Montréal. Ville de Montréal.

Ville de Montréal. (2007). Montréal, ville apprenante, de Savoir et d'innovation. Ville de Montréal.

Wynne, D. (1992). Urban regeneration and the arts. In D. Wynne (eds), The Culture Industry, Averbury: Aldershot.

\section{Notes}

Note 1: Policy makers have to support the revitalization process and they have to be able of encouraging and implementing local urban process of cohesion both financing activities of urban planning and enhancing processes of clustering agglomeration.

Note 2: Culture means considering Barcelona and Montréal in their renewal process: 
(i) Paradigm of reference on which the action of urban planning of the most depressed and degraded areas, both central and peripheral, is built.

(ii) Fundamental paradigm to redefine the strategic purposes and urbangovernance actions.

(iii) Main factor on which rebuild the city's identity (Montreal: Metropole Culturelle 2007-2017) (Barcelona: creative city of Europe).

(iv) Element of reference to redefine and to rebuild the urban space in terms of creativity, innovation, technology and social coeshion.

Note 3: The CCCB has been founded in 1994 with a complex private-public strategy aims to riqualify the religious center of "CASA de la CARITAT". It is very intersting that the local actors and cultural promoters of Barcelona have found their inspiration oserving the model Centre Pompidou in Paris. Although, they have established to build and plan the CCCB by a horizontal and decentralized dimension, more flexible and open to visitors and local communities (Rius, 2006). We have chosen the CCCB as important actor of development and we have decided to make an intervier to the Director because it was the first cultural element that has contributed to transform the Raval.

Note 4: An important role is played by the CDEC (Corporation de Développement Économique Communautaire) that is a Local Economic Development Agency embedded in the territory with an evident incidence and strategic role in the social and economic life of every quarter and "arrondissement" in Montréal. They are really important because, as public development agencies, they represent and link together all the associations, groups and actors who are active and dynamic in the process of planning and revitalization of depressed and poor areas.

Table 1. Increase of immigrants in the 10 districts of Barcelona between 2000-2010

\begin{tabular}{|l|l|l|l|}
\hline & \multicolumn{1}{|c|}{2001} & \multicolumn{1}{c|}{2010} & \multicolumn{1}{c|}{$2000-2010$} \\
\hline 1. Ciutat Vella & 15.513 & 41.281 & $166,1 \%$ \\
\hline 2. Eixample & 13.386 & 46.823 & $249,8 \%$ \\
\hline 3. Sants-Montjuïc & 8.585 & 35.015 & $307,9 \%$ \\
\hline 4. Les Corts & 3.320 & 9.320 & $180,7 \%$ \\
\hline 5. Sarrià-Sant Gervasi & 5.939 & 16.263 & $173,8 \%$ \\
\hline 6. Gràcia & 4.805 & 18.982 & $295,0 \%$ \\
\hline 7. Horta-Guinardó & 4.850 & 21.808 & $349,6 \%$ \\
\hline 8. Nou Barris & 4.961 & 27.100 & $446,3 \%$ \\
\hline 9. Sant Andreu & 4.057 & 19.109 & $371,0 \%$ \\
\hline 10. Sant Martí & 7.019 & 34.948 & $397,9 \%$ \\
\hline BARCELONA & 74.019 & 270.649 & $284,5 \%$ \\
\hline
\end{tabular}

Source: Ajuntament de Barcelona. 
Table 2. Concentration of immigrants-residents in each district in comparison with total resident

\begin{tabular}{|l|l|l|l|l|l|l|l|l|l|}
\hline & 2001 & 2002 & 2003 & 2004 & 2005 & 2006 & 2008 & 2009 & 2010 \\
\hline Ciutat Vella & $18,2 \%$ & $26,7 \%$ & $34,7 \%$ & $36,1 \%$ & $35,6 \%$ & $38,5 \%$ & $39,7 \%$ & $40,9 \%$ & $40,5 \%$ \\
\hline Eixample & $5,4 \%$ & $8,0 \%$ & $11,2 \%$ & $13,7 \%$ & $15,1 \%$ & $16,4 \%$ & $17,2 \%$ & $18,1 \%$ & $17,7 \%$ \\
\hline Sants-Montjuïc & $5,1 \%$ & $8,2 \%$ & $12,0 \%$ & $14,7 \%$ & $16,1 \%$ & $17,8 \%$ & $19,0 \%$ & $19,6 \%$ & $19,3 \%$ \\
\hline Les Corts & $4,0 \%$ & $5,3 \%$ & $7,4 \%$ & $9,0 \%$ & $10,0 \%$ & $11,2 \%$ & $11,1 \%$ & $11,8 \%$ & $11,4 \%$ \\
\hline Sarrià-Sant Gervasi & $4,6 \%$ & $5,8 \%$ & $7,9 \%$ & $9,8 \%$ & $10,7 \%$ & $11,4 \%$ & $11,4 \%$ & $12,0 \%$ & $11,4 \%$ \\
\hline Gràcia & $4,2 \%$ & $6,3 \%$ & $9,0 \%$ & $11,6 \%$ & $12,9 \%$ & $14,0 \%$ & $14,8 \%$ & $15,8 \%$ & $15,6 \%$ \\
\hline Horta-Guinardó & $2,9 \%$ & $4,8 \%$ & $7,0 \%$ & $8,7 \%$ & $9,8 \%$ & $11,1 \%$ & $12,5 \%$ & $13,1 \%$ & $12,9 \%$ \\
\hline Nou Barris & $2,9 \%$ & $5,1 \%$ & $7,7 \%$ & $10,0 \%$ & $11,6 \%$ & $13,5 \%$ & $16,0 \%$ & $16,8 \%$ & $16,3 \%$ \\
\hline Sant Andreu & $3,0 \%$ & $4,8 \%$ & $7,2 \%$ & $8,8 \%$ & $10,0 \%$ & $11,3 \%$ & $12,8 \%$ & $13,3 \%$ & $13,2 \%$ \\
\hline Sant Martí & $3,4 \%$ & $5,5 \%$ & $8,3 \%$ & $10,3 \%$ & $11,8 \%$ & $13,2 \%$ & $14,7 \%$ & $15,3 \%$ & $15,3 \%$ \\
\hline Barcelona & $4,9 \%$ & $7,6 \%$ & $10,7 \%$ & $12,8 \%$ & $14,6 \%$ & $15,9 \%$ & $17,3 \%$ & $18,1 \%$ & $17,6 \%$ \\
\hline
\end{tabular}

Source: Ajuntament de Barcelona.

Table 3. Processes of cultural regeneration in Raval and Mile End

\begin{tabular}{|c|c|}
\hline RAVAL & MILE END \\
\hline $\begin{array}{l}\text { Consolidate cultural clustering quarter and emerging evolved } \\
\text { cultural district (MACBA-CCCB-UB-FED-CIDOB). }\end{array}$ & $\begin{array}{l}\text { Artistic and creative quarter and emerging } \\
\text { polycentric cluster embedded into the old } \\
\text { industrial buildings ( } 6-8 \text { blocks). }\end{array}$ \\
\hline Developed clustering process (top-down). & Latent clustering process (bottom-up). \\
\hline $\begin{array}{l}\text { Significant strategy of urban planning supported by Local } \\
\text { Institution and National Government (top-down). }\end{array}$ & $\begin{array}{l}\text { Not relevant actions and strategies for urban } \\
\text { planning and buildings rehabilitation. }\end{array}$ \\
\hline Culture-led regeneration approach (top-down). & Cultural regeneration approach (bottom-up). \\
\hline High concentration of cultural facilities. & Dispersed and spontaneous cultural activities. \\
\hline $\begin{array}{l}\text { Intensive critical mass and artistic atmosphere (top-down and } \\
\text { bottom-up processes). }\end{array}$ & $\begin{array}{l}\text { Ubisoft, artist run-centers, creative firms, } \\
\text { galleries and studios (bottom-up process). }\end{array}$ \\
\hline $\begin{array}{l}\text { Integration and proximity (physical, institutional and } \\
\text { organizational dimensions). }\end{array}$ & $\begin{array}{l}\text { Not a real spatial integration and mutual } \\
\text { organization among actors and artists. }\end{array}$ \\
\hline Social diversity and multi-ethnic dimension. & Social diversity. \\
\hline $\begin{array}{l}\text { Strong process of recent immigration by North Africa, East } \\
\text { Europe and Latin America. }\end{array}$ & Immigration (not recent) and gentrification. \\
\hline Intensive retail activities. & Emerging retail activities. \\
\hline Intensive tourism flows and touristic events. & Not tourism activity. \\
\hline $\begin{array}{l}\text { Emerging of social cohesion process and common practices of } \\
\text { participation into local governance framework. }\end{array}$ & $\begin{array}{l}\text { Specific "mile-end" territorial identity and } \\
\text { emerging citizen participation in the process of } \\
\text { regeneration. }\end{array}$ \\
\hline Strong international identity and territorial branding. & $\begin{array}{l}\text { Regional and national identification as cultural } \\
\text { neighborhood. }\end{array}$ \\
\hline
\end{tabular}

Source: Our Field Survey, 2011. 
Table 4. Main characteristics and actors of Raval and Mile End

\begin{tabular}{|c|c|}
\hline Raval & Mile-end \\
\hline \multicolumn{2}{|c|}{ Nature of cultural and artistic quarters } \\
\hline $\begin{array}{l}\text { Consolidate and developed cluster in terms of cultural } \\
\text { facilities, multi-dimensional spaces and artistic } \\
\text { infrastructure. } \\
\text { Old industrial spaces and marginalized areas }\end{array}$ & $\begin{array}{l}\text { Recent process of emerging cluster of cultural } \\
\text { and creative industries embedded into the old } \\
\text { industrial buildings ( } 6-8 \text { blocks). } \\
\text { Depressed areas and no functional complex of } \\
\text { buildings. }\end{array}$ \\
\hline
\end{tabular}

Emerging evolved cultural district as a territorial model for socio-economic development based on the integration process of innovation, creativity, human capital and infrastructure clustered around major players as MACBA, CCCB, UB, CIDOB, School of Art and Design Massena, National Library of Catalunya, Centro de EstudyCatalà

Potential integration between vertical and horizontal networks of different economic sectors driven by culture-led regeneration approach for boosting local economies as well as consumption entertainment cluster.

It is an "incremental cluster according to the role of actors and to the process of territorial organization. It means that a fundamental action of actors has supported and governed by "the Barcelona Model" of development partnership between public and private players. In addition, the cultural cluster is important not only as territorial and physical agglomeration but, mostly, as an organizational and relational process of development.

(iii) Role of actors

The main actors (MACBA, CCCB, UB, District Ciudad Vella, Barcelona Council, FONCIVESA, TOT-RAVAL, associations of artists and social groups) play a significant role in terms of finance, participation, organization, management, networking activities.

The model of development is based on dual dimensions: (i) Top-down approach which has supported and financed by institutions (Generalitat de Barcelona, Diputaciò de Barcelona, Banca de Catalunya, Caixa de Catalunya, FOCIVESA) (ii) Bottom-up approach oriented and elaborated by local communities and associations (like TOT-RAVAL) and Artist Galleries like (Galleria des Angels) for increasing and fostering the process of socio-economic regeneration.

\section{(iv) Integration}

EMERGING EVOLVED CULTURAL DISTRICT based Lack of integration and more dispersed spatial on synergy,complementarities and creative atmosphere among a lot of players and sectors (Culture, Tourism, Technology, Commerce, Retail) in the quarter embedded and concentrated in a unique territory.

(v) Creativity

New coalitions of actors $\quad$ Strong relationship between creative artists,

(Culture-Technology-Education-Social Life) and new galleries and creative firms like UBISOFT.
Emerging artistic and creative cluster industries based on the networking platforms between groups of artists and new innovative firms embedded in the same buildings and blocks (artistic run-centers and creative firms in the fields of design, communication, multimedia, architecture and social economy) - no presence of real cultural buildings and infrastructures.

Formal and informal relations between artists and cultural players, private firms and local institutions (CDEC-Ville-Local Council) for boosting the process of agglomeration - It is an emerging cluster production and promotion oriented.

The lack of important public/private institutions cultural oriented like museums, multi-functional spaces and auditoriums.

Ubisoft is a significant actor in fostering and encouraging cultural and artistic activities.

\begin{abstract}
The process of development in terms of policy and role of actors has oriented by an "auto-promotion" and "self-management" strategies (bottom-up) at the beginning of cultural change between networks of artists like artist runcenters), CDEC and associations. Main artistrun-centers: Agence TOPO, Articule, Atellier Circulaire, Dare-Dare, Diagonale, Clark Agency, LA CENTRALE, Galerie Powerhouse.
\end{abstract}


spaces (CCCB) for an emerging international platform of creativity based on LAB-RAVAL where CREATIVITY, CITY, and TECHNOLOGY are 3 fundamental paradigms of qualitative growth.

(vi) Empowerment

Providing support to community groups' giving local people "active participation"; helping to provide solutions to problems; giving local people a role in policy processes (TOT-RAVAL is the actor as a foundation that works on these trajectories and objectives).

Source: Our Field Survey, 2011.

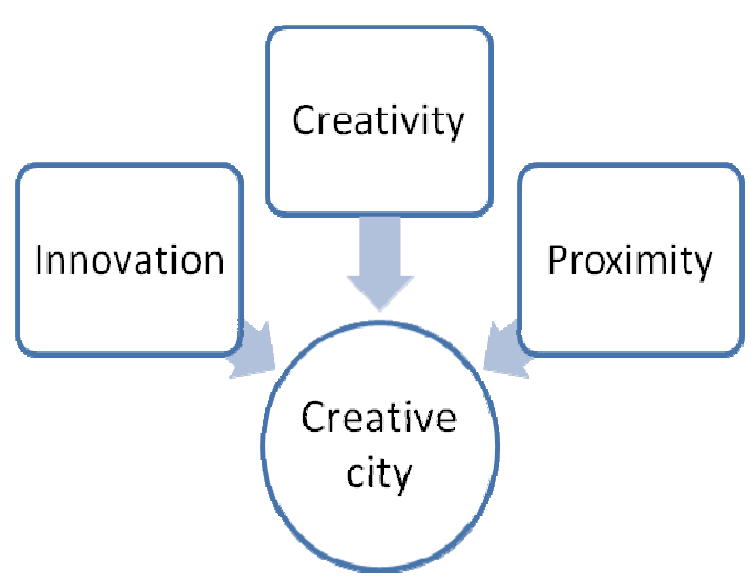

Figure 1. key factors of emerging creative cities in terms of clustering development process

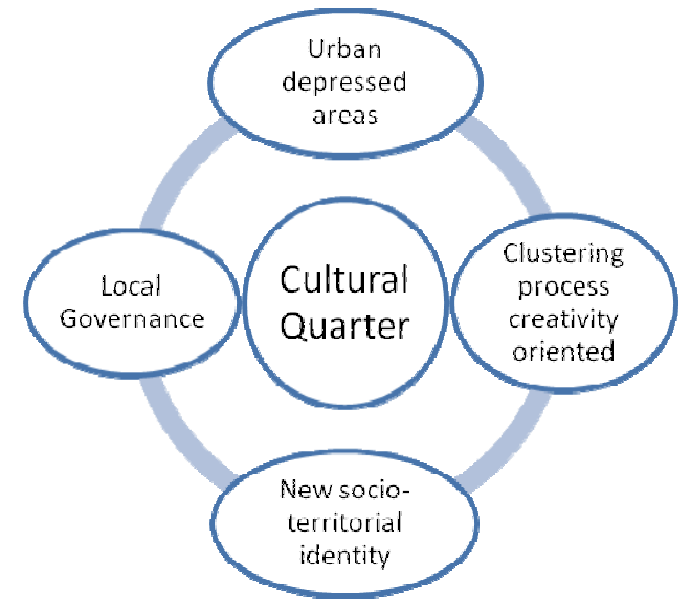

Figure 2. Factors of development of cultural quarters

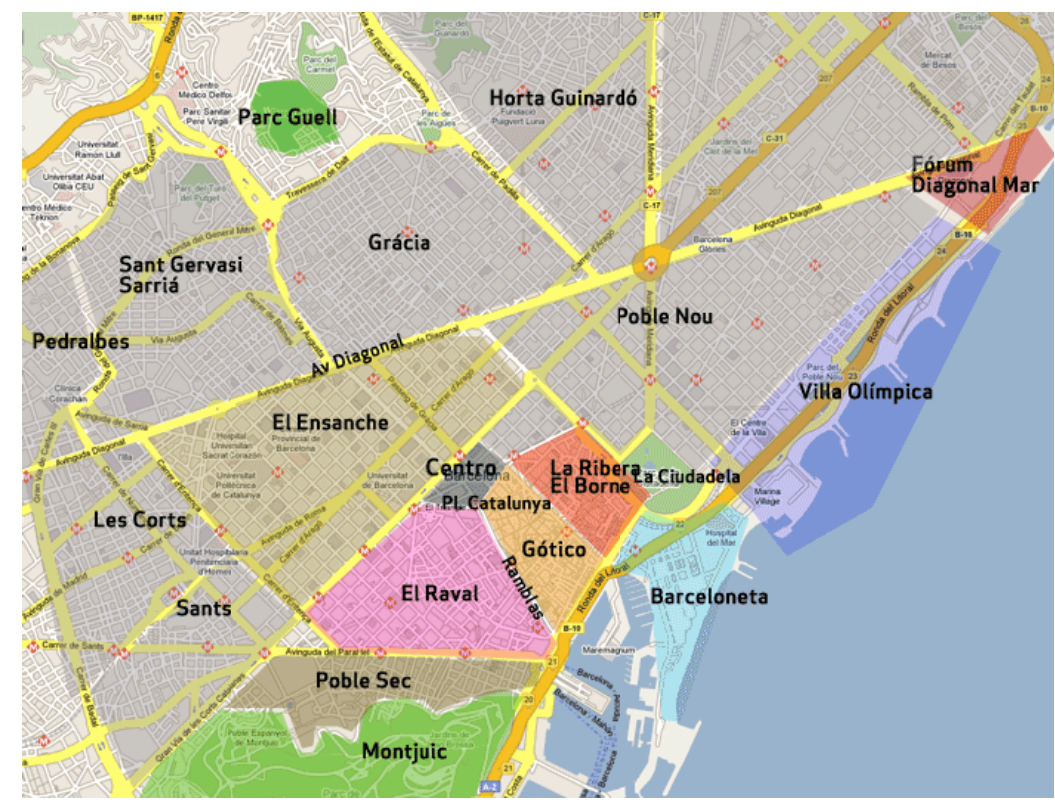

Figure 3. The Ciutat Vella District and its four neighborhoods (El Raval, Gotico, La Ribera, Barceloneta) 


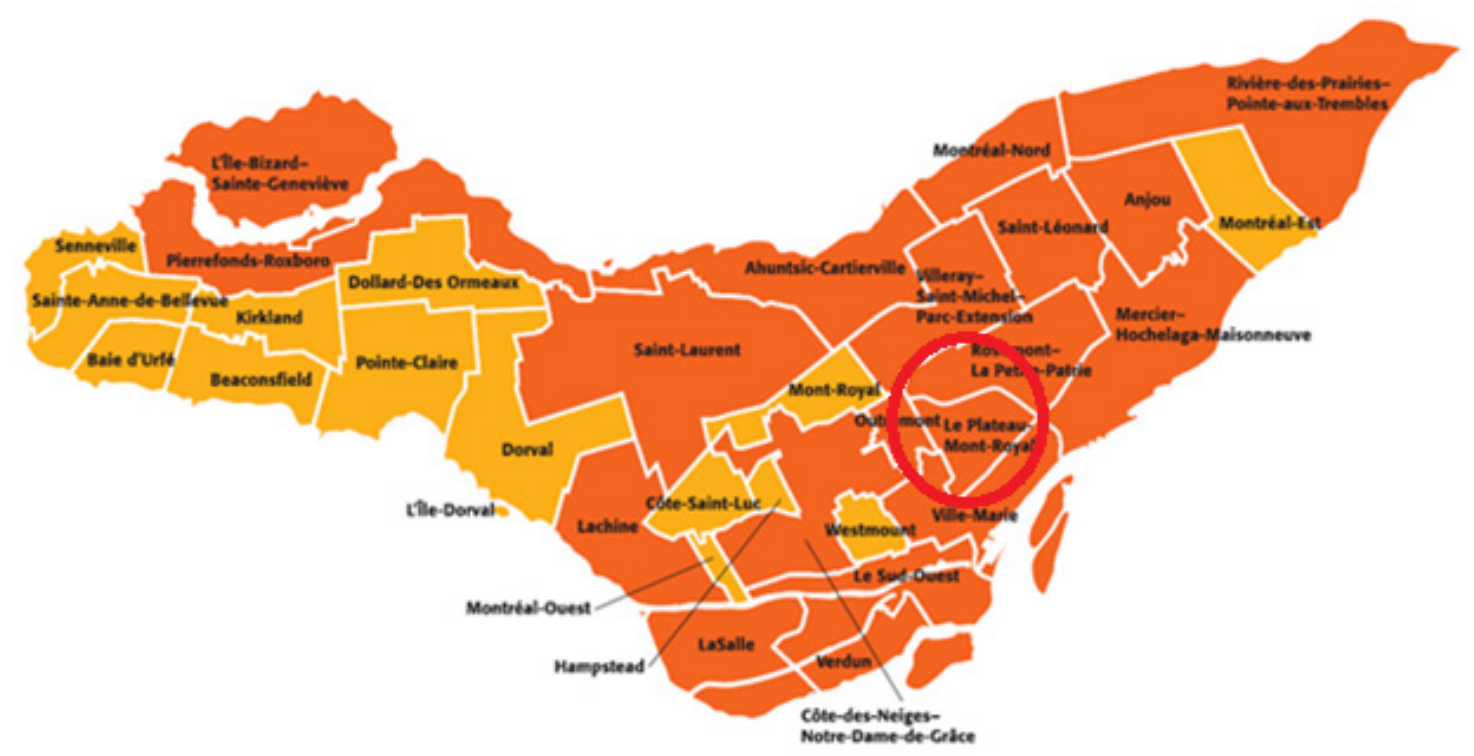

Figure 4. Montreal, its Districts (Arrondissements) and suburbs

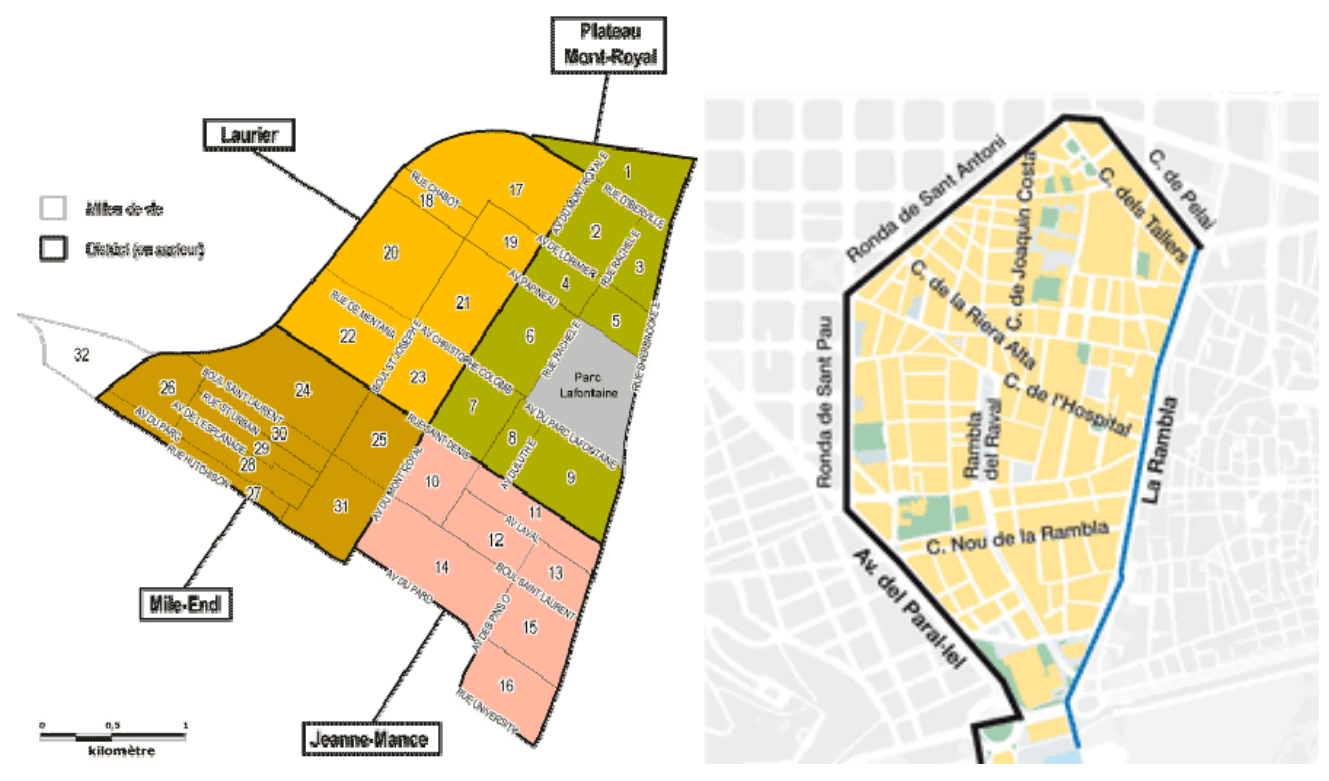

Figure 5. Mile-End and Raval 